\title{
The Business Service Sector in India, Ireland and Poland. A Comparative Analysis
}

\author{
Arkadiusz Mroczek \\ Ph.D., Krakow University of Economics \\ Faculty of Economics and International Relations \\ Department of International Economic Relations, Krakow, Poland \\ e-mail:mroczeka@uek.krakow.pl
}

\section{Abstract}

The fast growth of the service sector is one of the characteristic features of the contemporary economy. Amongst other CEE countries, Poland is one of the emerging locations for this sector. The aim of the paper is to examine and compare the business service sector in India, Ireland and Poland. Both India and Ireland are exceptional locations for this industry, so comparing the state and operating conditions in Poland with those countries can be insightful. A literature study is used to determine the motives of companies undertaking offshore investments, upon which a selection of location factors is made. In the empirical part, those factors are analyzed in a descriptive way. This allows us to draw conclusions concerning this sector in Poland. This country, to some extent, possesses selected positive features of both India and Ireland, which explains the current growth of the sector.

Keywords: Business Process Outsourcing, Business Service Sector, BPO, SSC, location choice

JEL: F21, F23, O32 


\section{Introduction}

The fast growth of the service sector is one of the characteristic features of the contemporary economy. Amongst other CEE countries, Poland is one of the emerging locations for this sector. The aim of the paper is an examination and comparison of the business service sector in India, Ireland and Poland. Both India and Ireland are exceptional locations for this industry. Comparing the state and operating conditions in Poland with those countries can be insightful, allowing us to draw conclusions concerning the latter.

In the 1970s and 1980s, the managerial mindset was dominated by internalization and vertical integration. This path of growth and full control was pursued by leading companies. Yet in the next decades, the international business world experienced a shift in paradigm that led to large scale outsourcing and offshoring projects (Kedia \& Mukherjee 2009, p. 258). Outsourcing can be understood as transferring certain processes to another firm basically to save costs and to focus on areas of key competence. If outsourcing is implemented on a wide scale, it drastically changes the role of the parent company. The value creation that was hitherto focused under one ownership and directcommand is now, in great part, disaggregated and dispersed between subcontractors. This way, a pyramidal model of subcontracting and horizontal networks can emerge. The parent organization in this model is an integrator that synthesizes the work of the contractors and benefits from the synergy effects that appear (Ramachandran \& Voleti 2004, pp. 49-62). Some authors argue that organizational forms have evolved in this way, from multinational enterprises to international networks (Grimes 2003, pp. 3-14).

For the benefits of outsourcing to be observed, both the parent company and the subcontractors can work in the same location. However, a great increase in value and its meaning are connected with another business phenomenon- offshoring. The latter is defined as the sourcing of activities outside a firm's home country and is sometimes referred to as global sourcing. This term emphasizes the ability of a company to take advantage of global resources by actively choosing locations in which it operates (Gooris \& Peeters 2014, p. 73-86). To use foreign resources, direct engagement is possible, which is called captive offshoring. Accessing these resources is also possible in an indirect way, through offshore outsourcing. In captive offshoring, a company creates a shared service center (SSC) in the host country that takes over processes from different locations. Offshore outsourcing is held in business process outsourcing (BPO) centers that usually work for many clients. In this paper, both forms of offshoring are taken together and often referred to as business sector services (BSS) or simply offshoring.

In history, the term offshoring referred implicitly to manufacturing production. The recent wave, however, concerns business services, including IT, administration, finance and call marketing, and it began, although very moderately, in the 1980s and 1990s. These kinds of business services have enormously increased in the $21^{\text {st }}$ century 
(Caniato et al. 2015, p. 189). The reasons behind this rise are both political-economic and technological. Both liberalization in Asia, as well as the fall of communism in Central and Eastern Europe, not only opened up consumer markets but they also enriched the global talent pool available for companies. The most pioneering cases were India and Ireland. India turned into a more business-friendly economy, and Ireland recognized business services as another niche for itself, after advanced manufacturing. The advances in computer technology and broadband Internet provided the necessary infrastructure (Metters \& Verma 2008, p. 142). The IT industry, itself, played another role in the development of business offshoring. During the "millennium bug" crisis in the 1990s, IT companies were looking for a way to fix the "date problem," and countries which offered cheap labor turned out to be the solution (Abbott 2013, p. 27). The service capacity that was created was then used to provide other kinds of IT services. The BPO industry, in general, was worth $\$ 45.6$ billion in 2000 , and $\$ 88.9$ billion in 2017, with the peak in 2014, when the total volume of its sales equaled $\$ 104.6$ billion (Statista, 2018).

\section{Methodological remarks}

First, a literature review is performed to determine companies' motives for undertaking offshore investments. The study continues by determining the factors that companies take into consideration when choosing the host country for BPO/SSC activities. We show that location factors can be connected with particular investment motives. Based on the set of factors prepared in the literature study, the empirical part is carried out. For some of the selected factors, proxy indicators are ascribed for which data on the three countries can be found. After presenting the factors, they are analyzedin a descriptive way. This allows us to draw conclusions concerning the sector in Poland.

\section{Literature review}

\section{Motives for making use of offshore business services}

Cost minimization is a primary motive for most companies deciding to outsource. As time passes, management can learn that outsourcing can bring more benefits, including quality improvement and innovation (Maskell et al. 2006, p. 3). Also, offshoring seems to be first driven by opportunities for cost reduction. However,other reasons, such as access to recourses and markets, also are important. Companies can benefit from the "resources and competencies arbitrage" that globalization brought to them (Munoz \& Welsh 2006, p. 112). Other authors have looked at this case from a similar perspective. Offshoring is initially driven by efficiency-seeking, usually in low 
value-added activities. But later, the quality of work and the pool of talent the parent company gains access to make it look for possibilities to rebuild its business model and improve the innovation process (Lewin \& Volberda 2011, p. 242), and benefit from new technologies and extra knowledge (Caniato et al., 2015, pp. 190-191; Musteen 2016, p. 3440).

Narrowing the considerations only to demanding high skills, research and development (R\&D) activities show an interesting analogy to the above pattern. According to Demirbag \& Glaister (2010, p. 1554), while the cost factor is still significant for companies offshoring their R\&D activities, a shortage of talent in their home countries appears to be of equal importance. A combination of the intention to gain access to cheaper assets, but also to rich technology (Jabbour \& Zuniga 2016, p. 359), as well as the possibility of benefiting from talented human capital (Benito et al. 2013, pp. 211-222) are often pointed out in this context. For some authors, captive offshoring and offshore outsourcing are, first of all, tools by which companies can take advantage of foreign sources of knowledge (Mukherjee et al. 2017, p. 1).

\section{Location factors of offshoring centers}

The framework for the discussion on the location choice of business service centers is based, in general, on the theory of foreign direct investment (FDI) location choice. The main concept exploited in this case is the eclectic OLI paradigm, which depicts the Ownership, Location and Internalization advantages that come from FDI. A theory also recalled is RBV (resource-based view),which emphasizes the company's resources as a key for its strategic choices. Another important approach, especially in the case of outsourcing, is TC (transaction cost theory), which underlines the cost of cooperating with an external service provider (Rodgers et al. 2017, pp. 1-12).

The results of studies based on those theories can be connected with the motives for undertaking offshoring projects. In short, the most important local features that attract this kind of companies are labor cost, the availability of resources (access to talent and human capital in general, the presence of service providers), and close cultural distance, business environment, and local networks. An attractive local market may also act as an incentive (Caniato et al. 2015, p. 190). The cost factor is the most commonly accepted factor, and it seems to be crucial especially at the initial phase of offshoring. The other features of the hosting economy are discussed more intensively, and the results of studies on them are interesting. One such empirical analysis shows that besides wages, a large educated workforce with language skills and low country risk play an important role in the case of any offshore business services, not only the most demanding R\&D (Doh et al. 2009, p. 938). Besides those factors, geographic distance and a country's previous BPO experience also often play a part (Graf \& Mudambi 2005, p. 264). Geographic distance appears to be a bigger obstacle, in terms of generating organizational and control problems, than cultural distance (Handley \& Benton 2013, p. 124). 
R\&D services demand high-quality human capital and the location of investments in this sector is also worth considering. For some authors, because companies use the offshoring of R\&D primarily as a tool to augment their knowledge base, a decisive location factor is the pool of skilled scientists and engineers (Demirbag \& Glaister 2010, p. 1555). Some studies suggest that companies tend to offshore projects that are more innovative to developed economies and routine R\&D tasks to emerging ones (Rodgers et al. 2017, pp. 1-12; Martinez-Noya et al. 2012, pp. 18-37).

Another useful insight into the topic of business service location can be given by analyzing how the specifics of particular companies influence their decisions in this field. One such factor is the company's experience in international offshoring, and lack of experience seems to make them prefer nearshore locations (Gerbl et al. 2015, p. 516). If a company is already present in a host country, it can encourage the company to make a fast decision to offshore business processes there (Luo \& Jayaraman 2013 , p. 460). The internal reasons for outsourcing and the particular activities that are going to be outsourced ("why and what" questions) may also be important (Hätönen 2009, pp. 72-73). Moreover, even some behavioral factors concerning the decision makers can be important for the choice of location. On the one hand, manpower and technology availability seem to dominate hedonistic factors (Rajkumar 2013, pp. 35-54); on the other hand, managers may choose a particular location not only based on in-depth economic calculation, but also on their emotional attitude towards the place (Musteen 2016 pp. 3439-3446).

BPO seems to be less path-dependent than many other kinds of industry, especially manufacturing. A combination of universal infrastructure and a certain level of human capital with general skills may be enough to start a new outsourcing center. Yet, it appears that also in this field, agglomeration factors may prove to be important. As Grossman and Helpman argue (2005, p. 158), for a client company, it is more profitable if it can choose between different providers in the same location, and for service companies, it pays off more if they have many customers to serve. This is a classic mechanism that drives agglomeration economies. This is why the business service sector also tends to focus in particular locations, forming clusters. Those clusters provide them with high-quality labor and other kinds of resources, this way improving their performance. What is important is the fact that in the case of emerging markets, those clusters are at the early stage of their development, so do not support companies to such an extent as those in the more developed locations (Upadhyayula et al. 2017, pp. 72-86).

Both the geographic scale, as well as the kind of agglomeration effects that appear, are interesting factors. A study on the service sector in England shows that agglomeration effects do not work at a local scale but can be recognized at a regional level. They were not visible in the case of particular cities (even London), but they did turn out to be present in the case of South-East England (Coe \& Townsend 1998, pp. 385400). Other research suggests that urbanization economies (the size of a city) turn out to be more important than localization economies in the case of attracting investments 
(Guimarães et al. 2000, pp. 132-133). Big cities and their regions are capable of providing workers who are both rich in terms of numbers, as well as highly diversified in terms of skills. This notion can be supported by findings from India, showing that BPO projects with higher knowledge specialization usually operate in the most developed cities. Projects that do not demand such a high level of skills tend to be located in less developed cities (Luo \& Jayaraman 2013, p. 460).

Table 1. BPO motives and location factors

\begin{tabular}{|c|c|c|}
\hline Type of a project & $\begin{array}{l}\text { Motives and expectations } \\
\text { of companies }\end{array}$ & Location factors of host countries \\
\hline \multirow{5}{*}{$\begin{array}{l}\text { General BPO } \\
\text { and routine } R \& D\end{array}$} & - cost reduction & - low labor cost \\
\hline & - quality improvement & $\begin{array}{l}\text { - high presence of service providers, } \\
\text { - BPO experience, } \\
\text { - low geographic and cultural distance, }\end{array}$ \\
\hline & -innovation & - -strong local business networking \\
\hline & - access to resources & $\begin{array}{l}\text { - access to human capital, } \\
\text { - large educated workforce, } \\
\text { - high language skills }\end{array}$ \\
\hline & - market access & - big demand on the host market \\
\hline $\begin{array}{l}\text { Innovative R\&D, } \\
\text { knowledge-intensive } \\
\text { services }\end{array}$ & $\begin{array}{l}\text { - knowledge, talent and } \\
\text { technology access, } \\
\text { - cheaper access } \\
\text { to resources, } \\
\text { - innovations, }\end{array}$ & $\begin{array}{l}\text { - pool of skilled scientist and engineers, } \\
\text { - labor costs less important, } \\
\text { - location in more developed economies }\end{array}$ \\
\hline \multicolumn{3}{|c|}{ Spatial features } \\
\hline $\begin{array}{l}\text { Presence of BPO } \\
\text { providers and human } \\
\text { capital }\end{array}$ & $\begin{array}{l}\text { - variety of service providers, } \\
\text { - large pool of human capital, } \\
\text { - highly specialized labor } \\
\text { force }\end{array}$ & $\begin{array}{l}\text { - large number of clients in the same } \\
\text { location, } \\
\text { - clusters providing talents and } \\
\text { specialized subcontractors, } \\
\text { - high presence of clusters in developed } \\
\text { economies, } \\
\text { - urbanization economies more } \\
\text { important than localization economies }\end{array}$ \\
\hline \multicolumn{3}{|c|}{ Government activity } \\
\hline Investments & $\begin{array}{l}\text { - hard and technological } \\
\text { infrastructure, } \\
\text { - availability of human } \\
\text { resources }\end{array}$ & $\begin{array}{l}\text { - well developed infrastructure, } \\
\text { - large pool of well-educated labor force }\end{array}$ \\
\hline $\begin{array}{l}\text { Administration } \\
\text { and legislation }\end{array}$ & $\begin{array}{l}\text { - low risk, } \\
\text { - low cost, } \\
\text { - general ease of doing } \\
\text { business }\end{array}$ & $\begin{array}{l}\text { - economic and political stability, } \\
\text { - competitive taxation, including labor } \\
\text { taxes, } \\
\text { - low administrative burden and good } \\
\text { investment climate }\end{array}$ \\
\hline
\end{tabular}

Source: own preparation.

Except for the structural factors presented above, local institutions also have an impact on attracting the BPO providers to a particular location. Governments together with their regional and local partners can shape the right legislation, and local agencies 
can both promote their offer for investors as well as provide them with necessary support (Kleibert 2014, p. 257). Moreover, in the long run, policies in the field of education and economic stability seem to be crucial also for the BPO sector. Especially interesting is the fact that in high political risk countries, the primary experience of a company seems to lower the value of this factor (Demirbag \& Glaister 2010, 1554).

A synthetic presentation of the above motions is presented in Table 1.

\section{The business service sector in India, Ireland and Poland}

Before the actual comparison of the three countries in question, some background to the development of BPO services in those countries will be provided. It should allow us to better describe the similarities and differences between them.

India is the world's leader in business services, and this industry itself is an important part of the Indian economy. It generates about 200,000 jobs each year, and the sector provides employment for 3 million people directly and about 9 million indirectly. As recently as in 2012, the share of GDP generated by the sector was estimated to be $7.5 \%$ (Raghunath 2014, p. 6). Those results are because liberalization in the country was introduced soon enough to be combined with the growing technology. Together with the impressive resources of a skilled English-speaking labor force, those factors gave India the first mover advantage (Abbott 2013, p. 29). Since the 1980s, India's BSS gained experience that allows it to be the first choice for many kinds of activities, including $R \& D$, although usually the more standardized activities. The main factor that seems to decrease India's competitiveness in this field is the great geographic distance to both the USA and Europe (Demirbag \& Glaister 2010). This disadvantage maybe one of the reasons behind the international expansion of some Indian companies (Thite et al. 2016, p. 443).

Around the turn of the millennium, Ireland was often pointed out as an example of an economic miracle. The country was located on the peripheries of Europe, and historically, even its proximity to Great Britain was more a source of exploitation than an economic partnership in modern terms. Even for decades after World War II, the British economy was not a source of economic stimulation for Ireland, yet a combination of objective factors and, as it turned out, well-designed government policy led to success. The restructuring of the British economy made it a source of investment that could be directed to the neighboring island, especially since English is the primary language there, as a heritage of the long British rule. This was also important for American companies, for whom the location of Ireland was not peripheral, but the closest EU member state to their shores. The country soon transformed into an export platform for them. The main policy incentives that were implemented were the low capital tax rates (10\%) that were first introduced in manufacturing in 1978 and extended to services in 1987. Also, an active role of the government agency (IDA) played a role in attracting some companies that were leaders in their industries (Barry et al. 2012, p. 2). Ireland became a high FDI intensive country, which led to a great increase in production and 
exports of high value-added products (Romalis 2006, p. 12). What is important is that after the initial period, in which the FDI income was basically cost driven, the agglomeration and demonstration effects started to play a crucial part. The Irish workers, and then the managers, adopted international standards of conducting business. They developed technical, managerial and soft skills, and some of them used them later to start their own companies. This, in turn, helped to create business networks that could attract more and more foreign investors (Ryan \& Giblin 2012, p. 1337; Grimes \& White 2005, p. 2185). The Irish ability to develop infrastructure and human capital was shown as the key factor of development when wage competitiveness was exhausted (Grimes 2003, p. 2185). The "Irish miracle" started with advanced manufacturing, but business services took their share from the 1990s. As early as 2003, Ireland was ranked as the leader in attracting offshore business services, comprising both IT and other processes. The Irish share was 8.3\%while India's was 7.7\% (Barry et al. 2012, p. 2).

Despite all the impressive achievements, the Irish economy was not free from weaknesses. A small country depending on exports and FDI had to be strongly affected by the international financial crisis of 2008. Moreover, in the case of Ireland, the effects were also strengthened by its own financial sector. As Honohan points out (2009, pp. 1-11), after 2000, the growth of the economy was led more by an immobility bubble, and the Irish banks fueled the boom with cheap credit, which was partly possible due to membership of the Eurozone. In these circumstances, the government lacked sound fiscal policy and bank sector regulation. This made Ireland suffer a three-year recession; however, after that, the economy regained its vigor. Although not free of turbulences over time, in 2018 Ireland is predicted to be the fasted growing EU member state (EC 2018). The strategy of building international competitiveness through advanced manufacturing and business services seems to be still valid.

Poland, amongst other CEE countries, inherited many disadvantages from the communist era. The education system, however, delivered relatively good quality human capital, including in the fields of science and technology. Demirbag and Glaister (2010) emphasize this as one of the most important factors driving BSS investments in the country. An industrial report shows Poland to be a well-established, low-risk country and as one of the arguments to support this, it shows that apart from the leading cities, such as Krakow, smaller ones are also beginning to attract investors (Heard et al. 2016, p. 14). The situation seems to resemble India, where such a net of BSS cities exists.

\section{Results and comparison}

Based on the location factors depicted in Table 1, a reduced list of factors, arranged according to the same groups, was created. The reduction allowed us to get factors that are differentiated, and the arrangement allows us to interpret them easily. Next, for each factor, a proxy indicator was chosen, allowing us to compare the countries based on hard data. The factors, indicators and their values are presented in Table 2. 
Table 2. India, Ireland and Poland location factors

\begin{tabular}{|c|c|c|c|c|c|}
\hline \multirow{2}{*}{$\begin{array}{l}\text { Group } \\
\text { of factors }\end{array}$} & \multirow{2}{*}{ Location factor } & \multirow{2}{*}{ Indicator } & \multicolumn{3}{|c|}{ Country } \\
\hline & & & India & Ireland & Poland \\
\hline \multirow[t]{3}{*}{ Human capital } & low labor cost & $\begin{array}{l}\text { average yearly salary of anac- } \\
\text { countant (thousands of euro) }\end{array}$ & 10 & 50 & 18 \\
\hline & $\begin{array}{l}\text { large pool of human } \\
\text { capital }\end{array}$ & $\begin{array}{l}\text { total university enrolment } \\
\text { (millions) }\end{array}$ & 36.6 & 0.225 & 1.6 \\
\hline & high language skills & $\begin{array}{l}\text { number of languages used } \\
\text { in the centers }\end{array}$ & 16 & 22 & 19 \\
\hline \multirow[t]{2}{*}{ Distance } & $\begin{array}{l}\text { low geographic } \\
\text { distance }\end{array}$ & $\begin{array}{l}\text { length of the flight from } \\
\text { New York/ London (h) }\end{array}$ & $\begin{array}{c}16.35 / \\
8.50\end{array}$ & $\begin{array}{c}6.15 / \\
1.15 \\
\end{array}$ & $\begin{array}{c}8.05 / \\
2.15\end{array}$ \\
\hline & low cultural distance & rank & 3 & 1 & 2 \\
\hline \multirow[t]{3}{*}{$\begin{array}{l}\text { Location } \\
\text { externalities }\end{array}$} & $\begin{array}{l}\text { high presence } \\
\text { of service providers }\end{array}$ & \multirow[t]{3}{*}{ sector present since } & \multirow[t]{3}{*}{1980} & \multirow[t]{3}{*}{1990} & \multirow[t]{3}{*}{2000} \\
\hline & $\begin{array}{l}\text { BPO experience } \\
\text { of a host country }\end{array}$ & & & & \\
\hline & $\begin{array}{l}\text { strong local business } \\
\text { networking }\end{array}$ & & & & \\
\hline \multirow[t]{4}{*}{ Governmental } & $\begin{array}{l}\text { well-developed } \\
\text { infrastructure }\end{array}$ & $\begin{array}{l}\text { average internet speed } \\
\text { (Mbits/sec.) }\end{array}$ & 2.8 & 12.8 & 11 \\
\hline & $\begin{array}{l}\text { economic and political } \\
\text { stability }\end{array}$ & $\begin{array}{l}\text { political stability index } \\
(-2.5 \text { to }+2.5)\end{array}$ & -0.83 & 1.02 & 0.52 \\
\hline & $\begin{array}{l}\text { competitive taxation, } \\
\text { including labor taxes }\end{array}$ & CIT rate (\%) & 35 & 12.5 & 19 \\
\hline & $\begin{array}{l}\text { low administrative } \\
\text { burden and good } \\
\text { investment climate }\end{array}$ & $\begin{array}{l}\text { Ease of Doing Business index } \\
\text { position }\end{array}$ & 100 & 17 & 27 \\
\hline \multirow{4}{*}{$\begin{array}{l}\text { Distinctive } \\
\text { for innovative } \\
\text { R\&D, } \\
\text { \&knowledge } \\
\text { intensive } \\
\text { services }\end{array}$} & $\begin{array}{l}\text { pool of skilled } \\
\text { scientists and } \\
\text { engineers }\end{array}$ & $\begin{array}{l}\text { number of science, technol- } \\
\text { ogy, engineering and math- } \\
\text { ematics graduates (thousands) }\end{array}$ & 2500 & 16.8 & 115.1 \\
\hline & \multirow{2}{*}{$\begin{array}{l}\text { clusters providing } \\
\text { talents and specialized } \\
\text { subcontractors, }\end{array}$} & $\begin{array}{l}\begin{array}{l}\text { number of research workers } \\
\text { (thousands) }\end{array} \\
\end{array}$ & 289 & 22 & 81 \\
\hline & & $\begin{array}{l}\text { number of research workers } \\
\text { per million inhabitants }\end{array}$ & 216 & 4575 & 2139 \\
\hline & $\begin{array}{l}\text { urbanization } \\
\text { economies }\end{array}$ & $\begin{array}{l}\text { number of cities above } \\
500000 \text { inhabitants }\end{array}$ & 88 & 1 & 5 \\
\hline
\end{tabular}

Source: Michael Page 2017, Robert Walters 2018, MoHRD 2018, HEA 2018, Eurostat, Business Standard, Deloitte 2016, PAIH, Google Maps, Fastmetrics, Theglobaleconomy, KPMG, World Bank, Forbes, Worldpopulationreview.

Demography is India's main advantage. The human capital in terms of the number of university students almost equals the living population of Poland. It is more than twenty times higher than the number of students in Poland, not to mention Ireland. Together with still relatively low wages, it is the basis of the service potential of India. Language skills seem to make no difference between the three countries. In contrast to the human potential, the physical distance seems to be a great disadvantage of the Indian locations. This can be seen most clearly in the case of cooperating with European partners. Also, cultural distance does not favor India, but its importance should not 
be overestimated, as the institutional system of India is partly based on Anglo-Saxon rules. As the pioneering country in the BPO industry, on the other hand, lets investors gain experience in operating there. This may explain their high activity in spite of the fact that, in terms of factors influenced directly by the government, India is far behind both of the European countries under consideration. Finally, at first sight, India's R\&D potential in the case of both the number of scientists and engineers, as well as possible spatial externalities, is impressive.

India's great potential and its pioneering role explain the fact, that, according to some estimations, in 2013 about $52 \%$ of the world's BPO/SSC market by value was located there (PWC 2014, p.4). Despite the impressive numbers, however, some concerns have arisen. A loud discussion was triggered by a report from consulting company Aspiring Minds (Newobserver 2018) which argued that " $95 \%$ of graduating engineers are not employable for software development jobs!" This referred to the low programming skills of the graduates. As the methodology of the report was not questioned, the fact was broadly accepted. It shows that there is a prevalence of quantity at the expense of quality. Even though India is an important location for R\&D activities, investors may still struggle to find the right employees. This fact is also important in the context of Poland and Ireland, as competitors of India.

Ireland is the most costly of the three locationswhen it comes to labor. The difference is great not only in comparison to India but also to Poland. In this small country, the number of university students is limited, which is another limitation of the Irish human capital. What acts in its favor is that it is closest to the USA and Western Europe physically and culturally, with a population for whom English is its native language. Its tradition of business services is almost as long as India's, and Ireland wins in every category classified under government activity. The good investment climate and competitive taxation are factors for which the island has been known for several decades, which makes those advantages even more effective.

Demography limits the number of $R \& D$ investments, although Ireland beats India and Poland in the category of researchers per million inhabitants. This indicator shows that this activity is more developed there and it is proportionally more important for Ireland'seconomy than in the case of the two other countries. It also supports the previously mentioned works showing that for more advanced $\mathrm{R} \& \mathrm{D}$ activities, more developed economies are the usual locations. High labor costs one hand, and demographic limitations on the other seem to leave Ireland no choice but to focus on high value added processes.

Poland still attracts investors with low labor costs. The number of university students is another important factor in the field of human capital. It cannot compete in this field with India, but the advantage over Ireland is strong. And the distance indicators work in favor of Poland when compared to its Asian counterpart. The history of business services in the country is relatively short, yet the disadvantage in this field is not big. In the case of the government-related factors, Poland is ahead of India and after Ireland, although closer to the latter. In the field of R\&D, the total poten- 
tial seems to be encouraging, both in terms of the quantity of staff as well as possible externalities. The share of researchers in the population is half that of Ireland, which shows that the two countries are at quite different stages in this field. However, the advantage over India is even more visible.

\section{Conclusion}

The three countries under consideration have a different history regarding the business service sector. India is the pioneer and still the leader, and this success is based on the great human potential of this country. Ireland is an example of good government practices that let it benefit from the advantages of proximity and skills. Poland is relatively new in the industry, yet it is often pointed out as a "rising star." It can be stated that, to some extent, the country possesses some of the positive features of both India and Ireland. The human potential, at least in terms of quantity, is bigger than in Ireland, and the language skills are not a problem. The great advantage over India is its proximity, especially to Western Europe. The quality of human capital also seems to work in favor of Poland, even though the economy is still less R\&D-oriented than Ireland. The government-related factors can be described as moderately favorable, although still less optimal than in Ireland. All of these circumstances explain the current inflow of business services investment to Poland quite well. What could be recommended from the policy point of view is a careful examination of the Irish case, as some solutions in this field can be used as benchmarks.

The obvious limitation of the study is the difficulty in finding comparable data in all the fields, which is often in the case of international comparisons. Also, the qualitative approach used here has its limitations but is appropriate for the purpose of this study. An area of possible future research is the quality of human capital in Poland, especially R\&D staff. This factor is not easy to diagnose but is crucial for the industry.

\section{References}

Abbott, P. (2013), How can African Countries Advance their Outsourcing Industries: An overview of possible approaches, "The African Journal of Information Systems", Vol. 5

Barry, F., Bergin, A. (2012), Offshoring, inward investment and export performance in Ireland, ESRI Working Paper, Vol. 430.

Benito, G.R.G., Dovgan, O., Petersen, B., \& Welch, L.S. (2013), Offshore outsourcing: A dynamic, operation mode perspective, Business Standard, Vol. 42 (2).

Caniato, F., Elia, S., Luzzini, D., Piscitello, L., \& Ronchi, S. (2015), Location drivers, governance model and performance in service offshoring, "Int. Journal of Production Economics", Vol. 163. 
Coe, N.M., \& Townsend, A.R. (1998), Debunking the Myth of Localized Agglomerations: The Development of a Regionalized Service Economy in South-East England, Transactions of the Institute of British Geographers, Vol. 23 (3).

Deloite (2016), Ireland's customer contact sector: Engaging talent in a changing environment

Demirbag, M., \& Glaister, K.W. (2010), Factors Determining Offshore Location Choice for R\&D Projects: A Comparative Study of Developed and Emerging Regions, "Journal of Management Studies", Vol. 47 (8).

Doh, J.P., Bunyaratavej, K., \& Hahn, E.D. (2009), Separable but not equal: The location determinants of discrete services offshoring activitie, "Journal of International Business Studies", Vol. 40 (6).

EC(2018), https://ec.europa.eu/ireland/news/highest-gdp-growth-for-ireland-in-2018_ en (accessed: 13.12.2018).

Fastmetrics, https://www.fastmetrics.com/internet-connection-speed-by-country.php (accessed: 13.12.2018).

Forbs, https://www.forbes.com/sites/niallmccarthy/2017/02/02/the-countries-with-themost-stem-graduates-infographic/\#27e5ca58268a (accessed: 12.18.2018).

Gerbl, M., McIvor, R., Loane, S., \& Humphreys, P. (2015), A multi-theory approach to understanding the business process outsourcing decision, "Journal of World Business", Vol. 50 (3).

Gooris, J., \& Peeters, C. (2014), Home-Host Country Distance in Offshore Governance Choice, "Journal of International Management", Vol. 20 (1).

Graf, M., \& Mudambi, S.M. (2005), The outsourcing of IT-enabled business processes: A conceptual model of the location decision, "Journal of International Management", Vol. 11 (2).

Grimes, S. (2003), Ireland's Emerging Information Economy: Recent Trends and Future Prospects, "Regional Studies", Vol. 37 (1).

Grimes, S., \& White, M. (2005), The Transition to Internationally Traded Services and Ireland's Emergence as a "Successful" European Region, "Environment and Planning”, Vol 37 (12).

Grossman G, Helpman R. (2005), Outsourcing in a Global Economy, "Review of Economic Studies", Vol. 72.

Guimarães, P., Figueiredo, O., \& Woodward, D., (2000), Agglomeration and the Location of Foreign Direct Investment in Portugal, "Journal of Urban Economics", Vol. 47 (1).

Handley, S.M., \& Benton, W.C., (2013), The influence of task- and location-specific complexity on the control and coordination costs in global outsourcing relationships, "Journal of Operations Management", Vol. 31 (3).

Hätönen, J. (2009), Making the locational choice,"Journal of International Management", Vol. 15 (1).

HEA, Higher Education Authority (Ireland), http://hea.ie/2018/01/31/student-numbers-in-ireland-top-225000 (accessed: 13.12.2018).

Hear, A., Polster, T., McLoclin, N. (2016), Where in the World? Cushman \& Wakefield Honohan, P. (2009), What went wrong in Ireland, Trinity College, Dublin. 
Jabbour, L., \& Zuniga, P. (2016), The Outsourcing of Research and Development in Global Markets: Evidence from France. The World Economy, Vol. 39 (3).

Kedia, B.L., \& Mukherjee, D. (2009), Understanding offshoring: A research framework based on disintegration, location and externalization advantages, "Journal of World Business", Vol. 44 (3).

Kleibert, J.M. (2014), Strategic coupling in "next wave cities": Local institutional actors and the offshore service sector in the Philippines, "Singapore Journal of Tropical Geography", Vol. 35 (2).

KPMG, https:/home.kpmg.com/xx/en/home/services/tax/tax-tools-and-resources/ tax-rates-online/ corporate-tax-rates-table.html (accessed: 13.12.2018).

Lewin, A.Y., \& Volberda, H.W. (2011), Co-evolution of global sourcing: The need to understand the underlying mechanisms of firm-decisions to offshore, "International Business Review", Vol. 20 (3).

Luo, Y., \& Jayaraman, V. (2013), Entry Strategies in Business Process Offshoring, "Journal of Leadership \& Organizational Studies", Vol. 20 (4).

Martinez-Noya, A., Garcia-Canal, E., \& Guillen, M.F. (2012), International R\&D service outsourcing by technology-intensive firms: Whether and where?, "Journal of International Management", Vol. 18 (1).

Maskell, P., Pedersen, T., Petersen, B., \& Dick-Nielsen, J. (2006), Learning Paths to Offshore Outsourcing - From Cost Reduction to Knowledge Seeking, "SSRN Electronic Journal", Vol. 13.

Metters, R., \& Verma, R. (2008), History of offshoring knowledge services, "Journal of Operations Management”, Vol. 26 (2).

Michael Page (2017), 2017 India Salary \& Employment Outlook, New Dehli 2017.

MoHRD (2018), Ministry of Human Resource Development Department of Higher Education, All India Survey on Higher Education 2017-18, New Delhi 2018.

Mukherjee, D., Lahiri, S., Ash, S.R., \& Gaur, A.S. (2017), Search motives, local embeddedness, and knowledge outcomes in offshoring, "Journal of Business Research", http://dx.doi.org/10.1016/j.jbusres. 2017.10.035 (accessed: 13.12.2018).

Munoz, J.M., \& Welsh, D.H.B. (2006), Outsourcing in the IT industry: The case of the Philippines, “The International Entrepreneurship and Management Journal", Vol. 2 (1).

Musteen, M. (2016), Behavioral factors in offshoring decisions: A qualitative analysis, "Journal of Business Research", Vol. 69 (9).

Newobserwer, http://newobserveronline.com/95-of-it-engineers-in-india-incapable-new-report-re veals/ (accessed: 13.12.2018).

PAIH, https://www.paih.gov.pl/sectors/bss\# (accessed: 13.12.2018).

PWC (2014), India - A destination for sourcing of services, PWC 2014.

Raghunath, A. (2014), Growth Achieved and Sustain by the BPO Sector in India, "Global Journal of International Economics and Research", Vol. 14 (1).

Rajkumar P., (2013), A Study of the Factors Influencing the Location Selection Decisions of Information Technology Firms, "Asian Academy of Management Journal", Vol. 18 (1).

Ramachandran, K., \& Voleti, S. (2004), Business Process Outsourcing (BPO): Emerging Scenario and Strategic Options for IT-enabled Services, "Vikalpa", Vol. 29 (1). 
Robert Walters (2018), Salary Survey 2018 Europe.

Rodgers, P., Khan, Z., Tarba, S., Nurgabdeshov, A., \& Ahammad, M.F. (2017), Exploring the determinants of location choice decisions of offshored R\&D projects, "Journal of Business Research”, doi:10.1016/j.jbusres.2017.11.009 (accessed: 13.12.2018).

Romalis, J. (2006), Capital taxes, trade costs and the Irish Miracle, "Journal of the European Economic Association", Vol. 5 (2-3).

Ryan, P., \& Giblin, M. (2012), High-tech Clusters, Innovation Capabilities and Technological Entrepreneurship: Evidence from Ireland, The World Economy, Vol. 35 (10).

Statista, https://www.statista.com/statistics/189788/global-outsourcing-market-size/ (accessed: 29.10.2018).

Theglobaleconomy, https://www.theglobaleconomy.com/rankings/wb_political_stability (accessed: 13.12.2018).

Thite, M., Wilkinson, A., Budhwar, P., \& Mathews, J.A., (2016), Internationalization of emerging Indian multinationals: Linkage, leverage and learning (LLL) perspective, "International Business Review", Vol. 25 (1).

Upadhyayula, R.S., Dhandapani, K., \& Karna, A. (2017), The Role of Cluster Presence and Quality Certification in Internationalization and Performance of Offshore Service Providers, "Journal of International Management", Vol. 23 (1).

World Bank, Ease of Doing Business 2018 (accessed: 13.12.2018).

World Bank, https://ata.worldbank.org/indicator/SP.POP.SCIE.RD.P6? view=chart (accessed: 13.12.2018).

\section{Streszczenie}

\section{Sektor usług dla biznesu w Indiach, Irlandii i Polsce Analiza porównawcza}

Szybki rozwój branży usług dla biznesu jest jedną z cech charakterystycznych współczesnej gospodarki. Razem z pozostałymi państwami Europy Środkowej i Wschodniej, Polska jest jednym z zyskujących na znaczeniu miejsc lokalizacji firm z tego sektora. Celem artykułu jest zbadanie i porównanie branży usług dla biznesu w Indiach, Irlandii i Polsce. Zarówno Indie, jak i Irlandia, są wyróżniającymi się miejscami dla lokalizacji usług tego typu. Dlatego też porównanie stanu i warunków funkcjonowania sektora w tych krajach i w Polsce wydaje się być ciekawe. W pracy przeprowadzono badania literaturowe w celu wskazania motywów podejmowania zagranicznych inwestycji usługowych przez firmy i wyboru czynników mających znaczenie dla lokalizacji centrów usługowych. W części empirycznej czynniki te zostały poddane analizie metodą deskryptywną w odniesieniu do badanych krajów. Pozwoliło to na wyciągnięcie wniosków dotyczących Polski. Do pewnego stopnia, Polska posiada niektóre pozytywne cechy zarówno Indii, jak i Irlandii. Tłumaczy to duży współcześnie napływ inwestycji z branży usługowej do Polski.

Słowa kluczowe: Sektor usług dla biznesu, usługi dla biznesu, BPO, SSC, wybór lokalizacji inwestycji 